$$
\begin{aligned}
& \text { DT \#46175 } \\
& \text { QH:NH } \\
& \text { II/22/2005 }
\end{aligned}
$$

MOL. 20060103.0044

\title{
Testing the Concept of Drift Shadow Using X-Ray Absorption Imaging
}

Aleeca A. Forsberg ${ }^{1.2}$, Susan J. Altman ${ }^{1}$, William J. Peplinski ${ }^{3}$, and Clifford K. Ho ${ }^{2}$

Environmental Science and Policy Department, UW-Green Bay, Green Bay, WI, ${ }^{2}$ Geohydrology, Sandia National Laboratories, Albuquerque, NM, ${ }^{3}$ American Staff Augmentation, Albuquerque, NM

\section{ABSTRACT*}

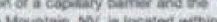

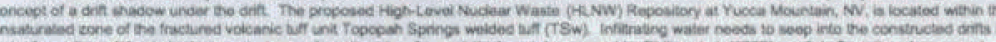

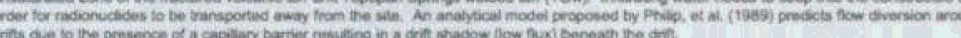

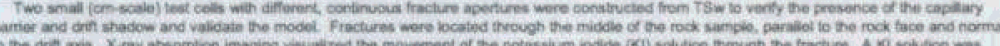

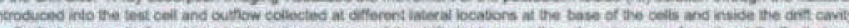

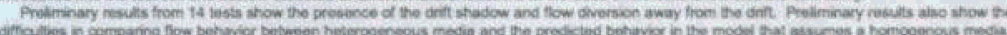

\section{INTRODUCTION}

The proposed HLNW storage repository at Yucca Mountain, NV is located in the unsaturated zone of a tractured voicanic tulf. in orcler to perform performance assessment calculations, it is necessary to quantify where fluid flows within the unit and how it may be affected by drift excavation. The analytical model of Philip et al. (1989) predicts that flow is diverted around the drift leading to an area of reduced flux beneath the drift, the drift shadow. The analytical model assumes a homogeneous, isotropic porous media, steady downward seepage through the media and spatially uniform flow velocity (Philip et al, 1989). The size of the drift shadow is dependant on drift diameter, capillary pressure and fracture aperture. The presence of a drit shadow, not accounted for in the current Yucce Mounte rom the waste emplacement container to the water table.

Our research focuses on the movement of fluid through fractures relative to the

excavated drift. In the test system, the fracture intersects the drift which allows us to predict whether or not we should expect seepage into the drift due to the intersection.

Preliminary results venity the existence of the dritt shadow and low diversion around the drift. Flow paths develop independent of flow rate and instead are controlled by geologic heterogeneities within the TSw.
CONCEPTUAL MODEL

ANALYTICAL MODEL

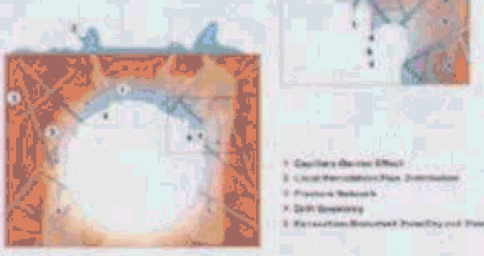

Conceptual Model of seepage into an excavated drith Percolation into the drit is variable and seepage is the dritt. Acrows show some drith diversion and small drift shadow.

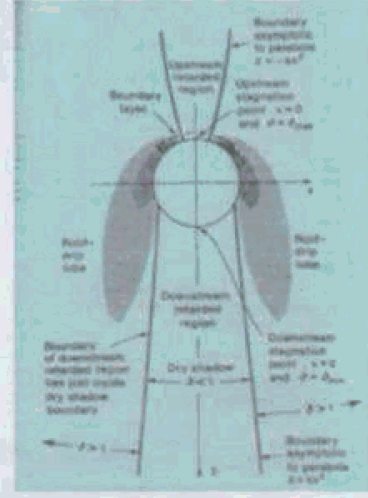
Analytical Model of seepage into an excavated drith, after seepage velocity which is diverted around the drift. Predictions include areas of increased saturation due to diversion, termed "root-drip lobes," and a region downstrear 


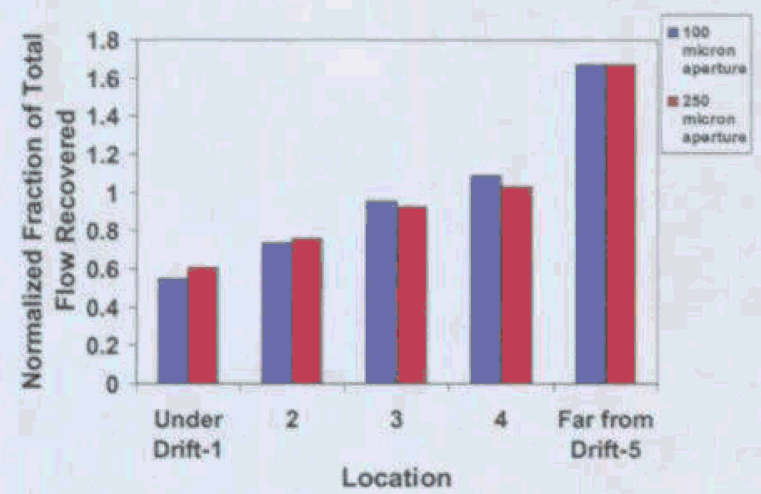

Analyticai model predictions indicated the location along the drit where we expect to see inflow recovered. Cumulative percent of inflow has been normalized assuming outflow at each port would be 0.20 without the
drift shadow. Therefore, values less than 1 assume fischarge less than if there was no drit shadow.

\section{METHODOLOGY}

\section{Test Cells}

Test cell dimensions of $10 \mathrm{~cm} \times 15 \mathrm{~cm} \times 1.25 \mathrm{~cm}$

- Two slabs pressed together aperture controlled by aluminum wire between 2 slabs

-100- $\mu \mathrm{m}$ aperture fracture

-250- $\mu \mathrm{m}$ aperture fracture

- Natural fracture present beneath drift of $250-\mu \mathrm{m}$ aperture fracture

- Fractures oriented normal to drift axis

- Aluminum bars put around the cell to decrease

$\mathrm{X}$-ray scatter

- Assembled cell encased in epoxy to decrease evaporative loss

\section{Experimental}

- Initially saturate sample with deionized water

- X-ray sample prior to start of experiment

- Initiate dripping of $\mathrm{KI}$ solution in ports at top of sample

- Outflow collected using sponges

- X-ray sample through out the experiment

- X-rays allow for visualization of $1-$ flowing through the sample

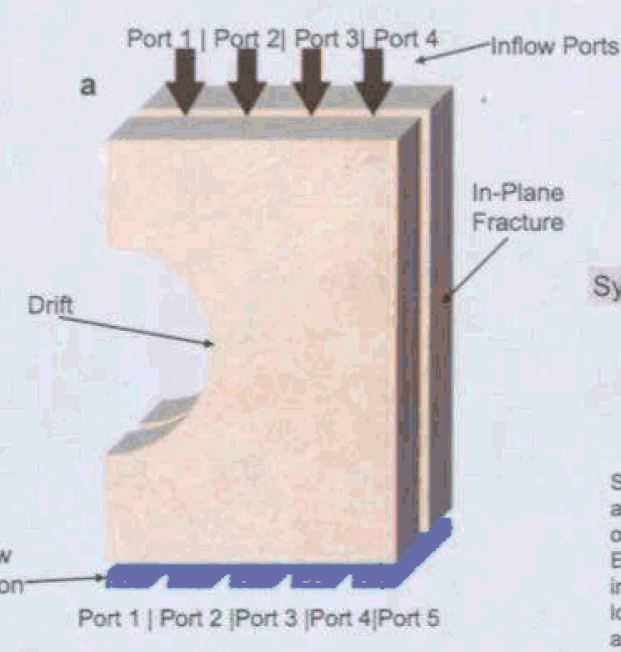

\section{Statistical Analysis}

- $\mathrm{H}_{0}$ : The analytical model predicts test system

- Chi Square Goodness of Fit test to compare the outflow results predicted in the model and those we observed

- Discharge into the drift not accounted for because it is not figured into model

- Used total cumulative percent of outflow at each port

- (observed-expected) $2 /$ expected into chi squared equation, 4 degrees of freedom

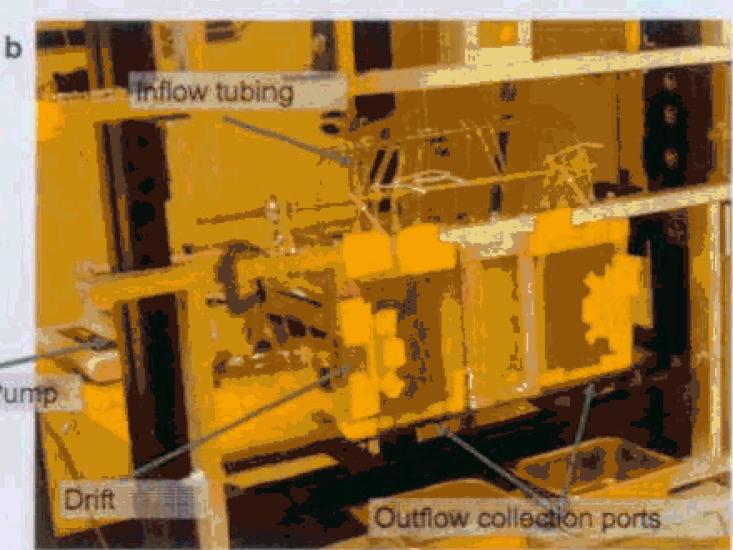

Schematic of test cell (a) and experimental set-up (b). Fracture is continuous throughout the test cel and is oriented perpendicular to the drift axis. Blue boxes beneath the cell (a) indicate the location of Experimental set-ip (p) includes 2 syringe pumps to control inflows rate, adrninistered by noints inserted into the fracture. Test cells are visible through epoxy caating, used to minimize evaporative losses to the system. Gold foll is taped to the epoxy to cover the Al frame surrounding the test cell and ower the drit area. This is done to minimize scatter of $x$-rays which may compromise the resulting $x$-ray image. 


\section{RESULTS}

\section{$100 \mu \mathrm{m}$-Aperture Fracture}

Table 1. Summary of four experiments performed on the $100 \mu \mathrm{m}$-fracture test cell. Listed flow rate is that which was programmed into syringe pumps and not necessarily that which actually flowed into the system. Mass balance was calculated using actual inflow rate.

\section{Flow Rate}

Test

est

Density of KI Mass Balance

Nomenclature Length $(\mathrm{min})$ Solution

Error (\%)

Cumulative.

p-value

(milmin

\begin{tabular}{|c|c|c|c|c|c|c|}
\hline 0.01 & $5 P$ & 485 & 1.09 & 10.1 & 0.80 & $1.71 \times 10^{-3}$ \\
\hline 0.05 & $2 P$ & 320 & 1.09 & 11.2 & 0.62 & $1.51 \times 10^{-41}$ \\
\hline 0.1 & $1 P$ & 126 & 1.09 & 7.9 & 0.21 & $1.15 \times 10^{-3}$ \\
\hline 0.15 & $3 P$ & 132 & 1.09 & 9.9 & 0.88 & $1.10 \times 10^{-19}$ \\
\hline
\end{tabular}

Test $3 \mathrm{P} ; 100 \mu \mathrm{m}$ aperture; Flow Rate $=0.15 \mathrm{ml} / \mathrm{min}$

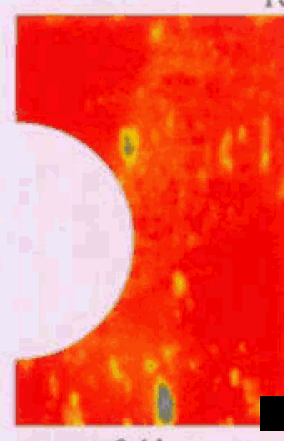

$\mathrm{t}=0.4$ hours

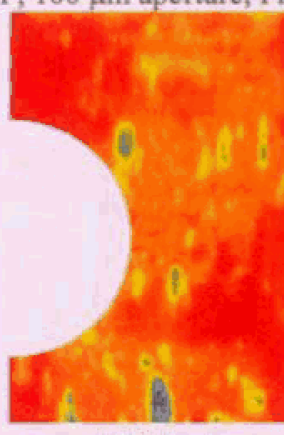

$\mathrm{t}=1.9$ hours

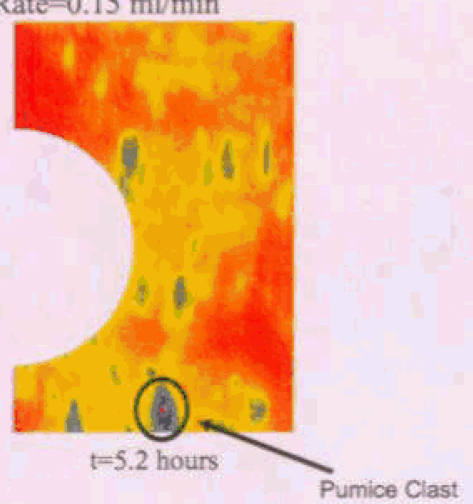

100 mm Fracture Aperture
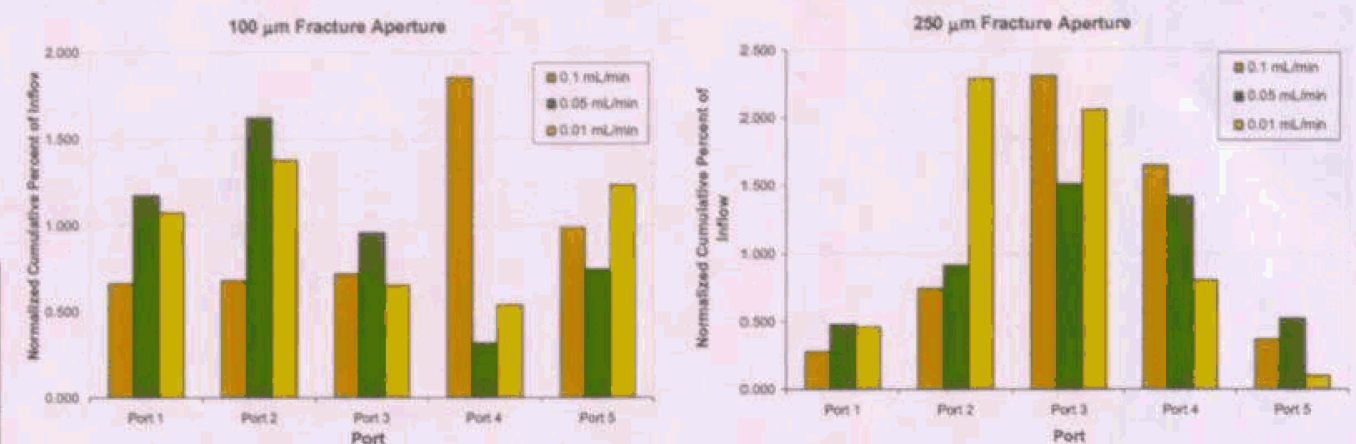

Comparison of observed outflow from three separate tests broken down by location along the base of the fracture. Cumulative percentage of inflow has been normalized assuming outflow at each port would be 0.20 without the drift-shadow effect. Therefore, values less than 1 assume discharge less than if there was no drift shadow effect.

\section{$250 \mu \mathrm{m}$-Aperture Fracture}

Table 2. Summary of the eight experiments performed on the $250 \mu \mathrm{m}$ fracture-test cell. Listed flow rate is that which was programmed into syringe pumps and not necessarily that which actually flowed into the system. Mass balance was calculated using actual inflow rate.

\begin{tabular}{|c|cc|c|c|c|c|}
\hline $\begin{array}{c}\text { Flow Rate } \\
\text { (milmin) }\end{array}$ & $\begin{array}{c}\text { Test } \\
\text { Nomenclature }\end{array}$ & $\begin{array}{c}\text { Experiment } \\
\text { Length (min) }\end{array}$ & $\begin{array}{c}\text { Density of KI } \\
\text { solution } \\
(\mathrm{g} / \mathrm{ml})\end{array}$ & $\begin{array}{c}\text { Mass } \\
\text { Balance } \\
\text { Error }(\%)\end{array}$ & $\begin{array}{c}\text { Cumulative } \\
\text { Discharge into } \\
\text { Drift (\%) }\end{array}$ & $\begin{array}{c}\text { P-value (Chi } \\
\text { squared) }\end{array}$ \\
\hline 0.01 & SP & 485 & 1.09 & -4.5 & 0.0 & $5.96 \times 10^{-19}$ \\
\hline 0.01 & $4 \mathrm{P}$ & 484 & 1.22 & -0.6 & 1.77 & $3.27 \times 10^{-39}$ \\
\hline 0.01 & $1 \mathrm{~B}$ & 428 & 1.09 & -15.4 & 1.72 & $3.24 \times 10^{-22}$ \\
\hline 0.05 & $2 \mathrm{P}$ & 320 & 1.09 & 10.1 & 1.27 & $1.71 \times 10^{-5}$ \\
\hline 0.05 & $6 \mathrm{P}$ & 419 & 1.09 & -11.6 & 0.6 & $1.72 \times 10^{-12}$ \\
\hline 0.1 & $1 \mathrm{P}$ & 126 & 1.09 & 1.6 & 0.22 & $6.18 \times 10^{-15}$ \\
\hline 0.1 & $2 \mathrm{~B}$ & 300 & 1.09 & 10.4 & 0.2 & $1.82 \times 10^{-7}$ \\
\hline 0.15 & $3 \mathrm{P}$ & 132 & 1.09 & 9.7 & 0.26 & $1.09 \times 10^{-7}$ \\
\hline
\end{tabular}




\section{(3) \\ 980190007]

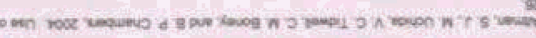

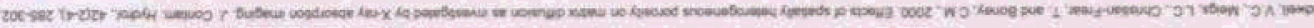

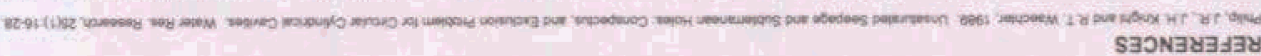

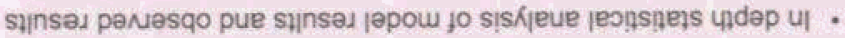

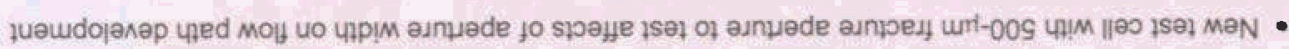

\section{Hวษ}

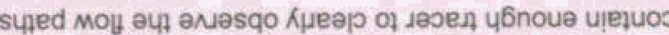
0) ॥eus 001 s!

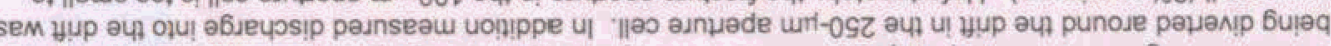

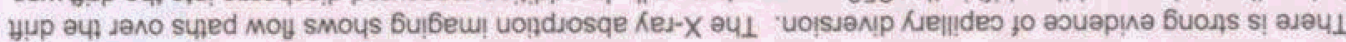

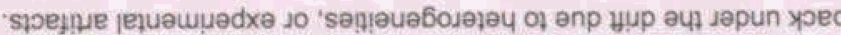

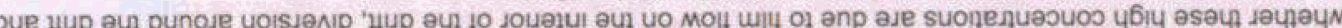

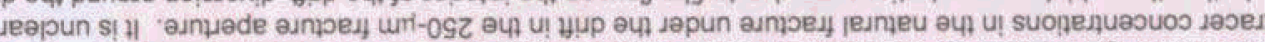

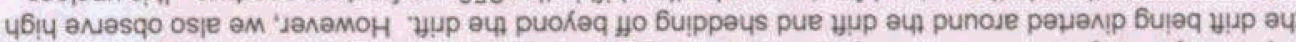

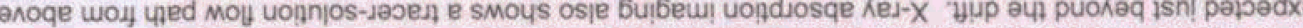

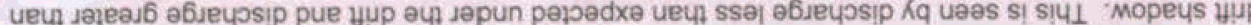

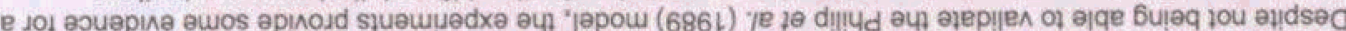

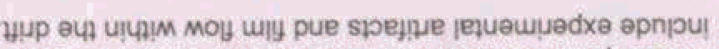

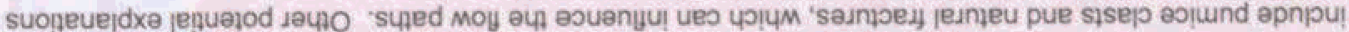

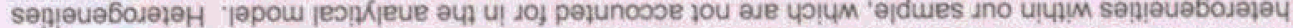

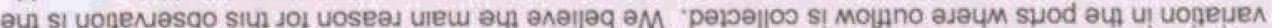

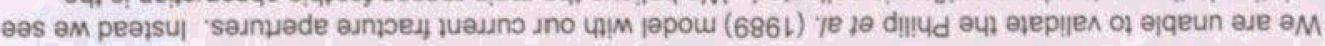

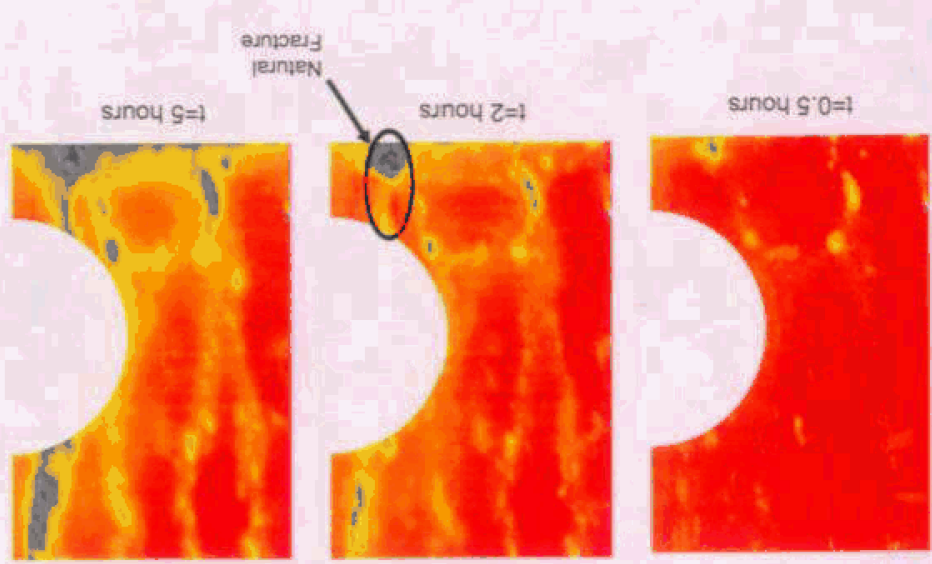

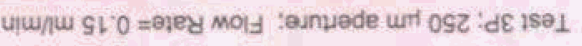

sunou $c=1$

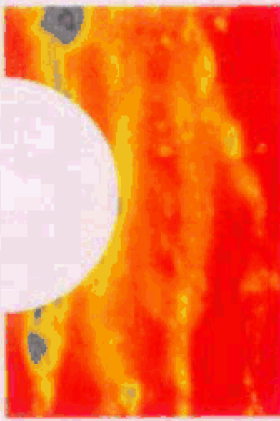

sinou $t=1$

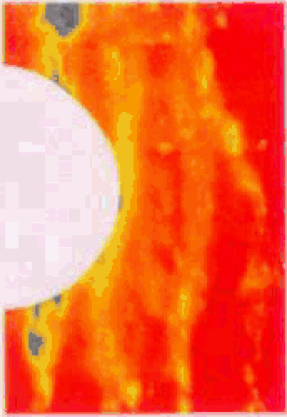

Sunou $\varepsilon^{\prime} \downarrow=1$

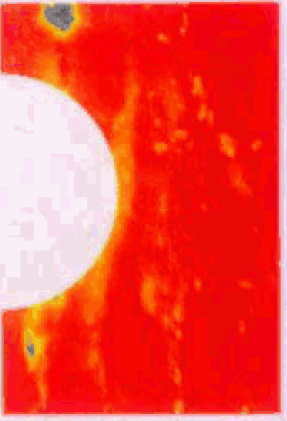

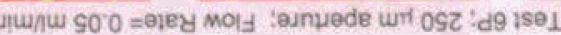

SNOISกาวNOJ GN甘 NOISSกJSIC 